\title{
The perception of Industry 4.0 in the managers of automobile distribution companies
}

\author{
Santos Ruiz Hernández \\ Marco Antonio Díaz Martínez \\ Herson Santos Ruiz Domínguez \\ Tecnológico Nacional de México, Instituto Tecnológico Superior de Pánuco \\ Veracruz, México
}

Keywords

Value Chain, Industry 4.0, autonomous production

\begin{abstract}
Industry 4.0 is originated in Germany in 2011, it is focused on optimize value chain through autonomous manufacturing and through technological systems; it's related with automotive sector as a product of international highly competitive. That is how the fourth industrial revolution started. The sector is very dynamic in Asia-Pacific, Mexico and United States. The goal of this investigation is to determinate three groups with respect to Industry 4.0, which allows them to identify new technology-based business strategies. The hypothesis shows that proposed methodology is useful to evaluate adopted strategies in the business to introduce the industry 4.0.

A transverse quantitative study was realized, using multivariate statistic and a population of 16 automobiles distributors located in three adjacent cities. An instrument was designed with six variables: Process, Product, Persons, Technology, Business and Social Responsibility. With 30 items; it was validated by Cronbach's alpha and it was used SPSS V25.

Three groups were determined with similarity shown in four indicator variables in the technology stage in industry 4.0. Groups were determined through ANOVA test. The most significant variables were analyzed by groups. A characterization of the variables was realized for their interpretation.

"Process" variable got the highest value among the three groups; the perception about productive process, services that they offer, and continuous improvement are positively identified at interior of the business. Process, Persons and Social Responsibility are the highest variables of the group three.
\end{abstract}

Corresponding author: Santos Ruiz Hernández

Email addresses for the corresponding author: santos.ruiz@itspanuco.edu.mx

First submission received: $20^{\text {th }}$ May 2019

Revised submission received: $12^{\text {th }}$ August 2019

Accepted: 21 ${ }^{\text {st }}$ August 2019

\section{Introduction}

Industry 4.0 (I4.0) is originated in Germany in 2011 as Fourth industrial revolution, with its implementation pretends to optimize value chain through autonomous manufacturing and information exchange (Blanco, González \& Rodríguez, 2007; Blanco, Fontrodona \& Proveda, 2017). I4.0 has influence on enterprises and those who manage it, decision-making in the industry is useful through communication technology adoption, it allows developing competitive advantage in the value chain of commercialized products (Bearzotti, 2017; Joyanes, 2017; Baena, Guarin, Mora, Sauza \& Retat, 2017).

The automotive industry is immersed in a great dynamism to a worldwide level especially AsiaPacific region, in Mexico this industry has grown like no other industrial sector (Basurto, 2013). The interaction between China, Mexico and United States have made closer for the manufacturing automotive industry in a significant way, at intern level has to compete in terms of value added, inversion, salaries and productive linkage (Ortiz, 2017). The importance of the automobiles distributors has effect on the car's value chain and in the competitive level of the product, a submitted sector to multiples pressures in the international environment. In this way, automobiles distributors must perceive new competence factors in the retail sector in that they operate. 
With the application of I4.0, Siemens Company managed to reduce marketing time by $30 \%$. As well as, they got an increment of 70,000 combinations in their Ghibli automotive model and increased the efficiency of their production system, thrice more than they used to had (SIEMENS, 2019). Ford have tried to change the way of build their products through technology, these efforts have resulted in a saving of $25 \%$ of the time used to make a change within the production line (Ford, 2019).

The goal of this investigation is to determinate the perception of managers of the automobile distributors with respect to Industry 4.0 as strategic element in the chain value of automotive sector. The hypothesis shows that proposed methodology is useful to evaluate adopted strategies and introduce the industry 4.0 in the business.

\section{Literature Review}

The concept of I4.0 is relatively new and it is still in construction; the debate of the production's digitalization has already started, and Germany seek to take leadership in this cluster of production technology (Schoeder, 2016). The I4.0 is built by 4 fundamentals factors: intelligent solutions, intelligent innovations, intelligent supply chain and smart factory; all these topics are linked by a new technological tool called Internet of Things (IoT) (Santos, Loures, Piechnicki \& Canciglieri, 2017). Although I4.0 is seen as the future of the enterprises, its application in different production process is still low (Santos, brittes, Fabián \& Germán, 2018).

With I4.0 is pretended to get independent products that can be monitored since any part of the manufacturing process; furthermore, it can optimize chain value to add value to the product (Blanco, González \& Rodríguez, 2007). Nowadays they are utilized electronic systems of control to increase the process capacity in automate form (González \& Rodríguez, 2017; Micheli \& Oliver, 2017). I4.0 has been enunciated as the integration of productive processes and related with hi-technology elements as big data, autonomous robots, simulation, integration of systems, industrial internet of things, cybernetic security, augmented reality and cloud storage (Pérez, Saucedo, Salais, \& Marmolejo, 2016).

New technologies have allowed developing products and prototypes in all disciplines for their commercialization; the influence of the digitalization and 3D printing is related with I4.0, this activity facilitates the experimentation with new products (Rodríguez et al., 2018). Business models have allowed giving added value to the commercialized product derived from advance and innovation technological, in counterpart, this has occasioned a product life cycle reduction, making them obsolete quickly (Cornelios \& Strandhagen, 2017; López, Pereira y Alves 2017; Müller \& Voigt, 2018). Intelligent manufacturing is considered as basic principle of the industry 4.0, while that smart products are considered as added value (German, Santos \& Fabián, 2019). Also, I4.0 make emphasis in the digitalization, optimization, product's personalization and value-added services ( $\mathrm{Lu}, 2017)$.

The development of a company is related with the capacity of generate competitive advantage based on innovation; in the interior of the organizations is attempted to improve processes, try with new products, as well as appropriate strategies for optimize resources (Robayo, 2016). The strategies utilized to make the enterprises more competitive, must include components such as: productive process, distribution, chain value and commercialization (Rodríguez, Balestrini, Balestrini, Romero \& Rodríguez, 2002; Cocca, Marciano, Rossi \& Alberti, 2018).

Business organizations have had the necessity of be more globalized, the personnel that is responsible for managing the systems of information, they have had to specialize to manage data bases, communications, language in technical knowledge to increase company's productivity (López, 2011). Enterprise competitive is so relevant that countries as Japan attracts qualified workers and international students to form themselves and be more competitive, with this action is pretended to have companies more competitive and appropriate personnel to strengthen economic business development (Méndez, 2017).

Training that is imparted in Higher education must consider the implementation of approaches related with I4.0, as automation, robotics, digitalization, internet of things, cybersecurity, big data, cloud services, 3D printing, augmented reality, information and communications technology, as well as, inclusion of new competences and the interdisciplinarity in the teaching-learning processes (Carbajal, 2017; Catalan, Serna \& Blesa, 2015). Thereby, the training provides opportunities to access to new knowledge that made professionals competitive and qualified in the enterprise (Román, 2010). 
Organizational Leadership in this topic of technology is hard to conceptualize, because there are multiple variables; the existing concepts make emphasis in the possibility of manage change in process productive, influencing work team and the human being's capacity to adopt technological aspects (Esguerra \& Contreras, 2016; Cano \& Baena, 2015; Munive, 2014). Technology inclusion in the enterprise has diversified around the world and different sectors as development and competitive (Ortega, 2014).

Nowadays the enterprises have implemented social responsibility actions as strategic part of their business model, with these actions enhance their results and generate a positive diffusion in the enterprise with a higher social acceptance; they procure to get financial positive results that is not against of politics in favor of social responsibility and environment (Setó \& Angla, 2011).

\section{Method}

The study is quantitative of transversal type, inferential and multivariate statistics were used to identify relation among variables. Population was 16 automobile distributors of registered trademark and located in three adjacent cities southerly of the Tamaulipas State, Mexico. It should be noted that automobile distributors of the study zone are 20 and only 16 decided to participate. An instrument was designed to measure the perception about industry 4.0 for executives or business managers of automobile distributor. It is planned this way because this is part of the chain value of the automobile sector; the designed instrument features six variables: Process, Products, Persons, Technology, business and social responsibilities, with five items for each variable to give a total of 30 items, that allow to develop an own instrument. Furthermore, a control question in which the executive and business managers were asked to evaluate from his perspective the level of adoption in their company concerning the industry 4.0.

The designed instrument is an approachment to the business sector to measure the perception about I4.0 to validate it, a pilot testing was applied and was submitted to test thru analysis of alpha Cronbach with .85 , Likert scale with seven answers was used. The trademarks of automobiles located in the zone, are presented in alphabetic order, as indicated: Chevrolet, Fiat-Chrysler, Ford, Honda, Hyundai, KIA, Mazda, Mitsubishi, Nissan, Peugeot, Renault, Suzuki, Toyota y Volkswagen.

The participants were the managers of the automobile distributors that provided information and they answered the questionnaire. To analyze the perception of the industry 4.0 was realized the method of $\mathrm{k}$-means clustering of three groups to determine the similarity between the organization of study and the variables (Process, Product, Persons, Technology, Business and Social Responsibility). The groups were determined through ANOVA, considering the largest number of significant F-test $(\mathrm{p}<0.05)$.

To identify if the perception of the respondent coincides with the result of the study's variable measurement, it was carried out a paired t-test between the variable of control and the average of the variables reported in the survey. Statistical analysis was realized with SPSS V25 Software.

\section{Results}

With obtained statistical data, we were able to identify the following information: the average age of the automobile distribution companies' managers is 33.6 years old, the youngest person in charge have 20 years old and the oldest is about 45 years old. Also $37.5 \%$ are men and $62.5 \%$ are women.

Hereunder, a k-means clustering test was realized to identify groups of concessionaire based on the valued variables through an instrument, three groups were determined according to the statistic similarity presented in four indicator variables above the level of advance in the adoption strategy in the industry 4.0 (Table 1.). It's possible to observe that group 3 presented the highest values for each of the significant variables for agglutination.

\begin{tabular}{|l|l|}
\hline \multicolumn{1}{|c|}{ Grupo } & \multicolumn{1}{|c|}{ Automotive Companies } \\
\hline Group 1 & Hyundai Tampico, KIA Avenida Hidalgo, Nissan Madero, Fiat Chrysler. \\
\hline Group 2 & $\begin{array}{l}\text { Mazda Tampico, Ford Automotriz Tampico, Suzuki Avenida Hidalgo, Honda, Chevrolet } \\
\text { Auto-Ideal, Toyota Tampico, Nissan Altamira. }\end{array}$ \\
\hline Group 3 & Volkswagen Megamotors, Peugeot, Mitsubishi Tampico, Renault Tampico, Nissan Tampico. \\
\hline
\end{tabular}

Table 1. determined groups according with their multidimensional distance by the k-means test 
The groups are determinate through ANOVA (see table 2), considering the largest number of significant F-test $(\mathrm{p}<0.05)$.

\begin{tabular}{|l|l|l|l|l|}
\hline Variables & Characterization of the variables & $\begin{array}{l}\text { Average } \\
\text { value for } \\
\text { Group 1 }\end{array}$ & $\begin{array}{l}\text { Average value } \\
\text { for Group 2 }\end{array}$ & $\begin{array}{l}\text { Average } \\
\text { value for } \\
\text { Group 3 }\end{array}$ \\
\hline Process* & $\begin{array}{l}\text { Knowledge of the productive process, } \\
\text { services that Enterprise offer, process } \\
\text { improvement }\end{array}$ & 5.90 & 5.26 & 6.16 \\
\hline Product & $\begin{array}{l}\text { product life cycle, technology } \\
\text { implementation in the company, } \\
\text { Digitization's benefits. }\end{array}$ & 6.50 & 6.40 & 6.68 \\
\hline Persons* & $\begin{array}{l}\text { Personnel productivity, personnel training, } \\
\text { strategies to improve the company }\end{array}$ & 5.45 & 4.94 & 6.32 \\
\hline Technology & $\begin{array}{l}\text { Technology acquisition, budget for } \\
\text { technological investment, use of electronic } \\
\text { media. }\end{array}$ & 5.25 & 6.00 & 5.80 \\
\hline Business* & $\begin{array}{l}\text { Implementation of technology, } \\
\text { business competitive advantage, strategies } \\
\text { for new products creation }\end{array}$ & 4.50 & 5.14 & 6.28 \\
\hline $\begin{array}{l}\text { Social } \\
\text { Responsibility } \\
*\end{array}$ & $\begin{array}{l}\text { Processes that do not affect environment, } \\
\text { sensitization about the importance of } \\
\text { environment, scraps and rubbish derived } \\
\text { of production. }\end{array}$ & 5.35 & 5.91 & 6.48 \\
\hline \multicolumn{2}{|l|}{ * Determinant variable of the group (p<0.05) in k-mean testing. } & & \\
\hline
\end{tabular}

Table 2. Results of the groups derived of the k-mean test and the characterization of each variable.

The proposed reflective type model presents satisfactory levels of validation and reliability. The variables (Processes, Products, Persons, Technology, Business, Social Responsibility) keep characteristics of homogeneity and one-dimensionality through the factorial analysis test with varimax rotation, this test in charge of analyze to increase of the factorial loads squared for each factor and that the results tend to approach 1 , while others approach 0 . With this we got a clearer belonging component of each variable. For the validation-convergent, Average Variance Extracted was calculated for each variable; higher values were obtained to 0.55 above 0.5 , which is the minimum value recommended (Hair, 2016). See table 3.

\begin{tabular}{|l|l|l|}
\hline Factor & Rotated component matrix, (Varimax) & AVE \\
\hline Process & -.108 & \multirow{2}{*}{0.55} \\
\hline Products & .060 & \\
\hline Persons & .415 & \\
\hline Technology & .859 \\
\cline { 1 - 2 } Business & .798 & \\
\hline \multicolumn{2}{|l|}{ Social Responsibility } & .787 \\
\hline
\end{tabular}

Table 3. Rotation matrix Varimax y AVE by construct.

As part of the procedure is estimated Variance Inflation Factor (VIF), it indicates that does not exist multicollinearity between pairs of constructs or independent factors, getting a maximum value of 3.05 (Chen, 2012), see table 4.

\begin{tabular}{|l|l|l|}
\hline Factor & Tolerance & VIF \\
\hline Process & .459 & 2.18 \\
\hline Products & .656 & 1.52 \\
\hline Persons & .339 & 2.94 \\
\hline Technology & .430 & 2.32 \\
\hline Business & .391 & 2.56 \\
\hline Social Responsibility & .327 & 3.05 \\
\hline
\end{tabular}

Table 4. Tolerance and VIF by construct. 
To measure the perception of the respondent with the result of the variables, a paired sample t-test was necessary to realize between the variable of control and the average of the variables reported in the survey, the results showed that response to the control variable does not correspond to what was answered for the study variables. That is to say, that the perception of the respondent doesn't correspond to the reality of the company, see table 5 .

\begin{tabular}{|l|c|}
\hline Analyzed variables & Significance \\
\hline Control & .045 \\
\hline Average Variables & \\
\hline Table 5. paired sample t-test between the variable of control and the average of the variables reported
\end{tabular}

in the survey

\section{Discussion and conclusion}

Three concessionaire distributors of automobiles groups were identified through the application of a measure instrument and evaluated by k-means clustering test. The organizations were integrated as indicated below, group 1: Hyundai Tampico, KIA Avenida Hidalgo, Nissan Madero, Fiat Chrysler; group 2: Mazda Tampico, Ford Automotriz Tampico, Suzuki Avenida Hidalgo, Honda, Chevrolet Auto-Ideal, Toyota Tampico, Nissan Altamira; group 3: Volkswagen Megamotors, Peugeot, Mitsubishi Tampico, Renault Tampico, Nissan Tampico.

For the discussion we analyze the most significant variable by groups. The variable "process" got the highest value in the group 3, this indicate that the perception about productive process, offered services and continuous improvement are identified positively into groups company; however, it can be seen that the variable was evaluated differently by the members of each group analyzed. There is similarity with the expressed by $\mathrm{Da}, \mathrm{Xu}$ \& Lí (2018) indicates that the standardization of processes of a global way would be ideal for industry 4.0 but the problem is while internet of things keeps growing, it would be difficult to standardize production process.

With regard to the variable "Persons", the highest value is identified in the group three, this indicate that the perception about personal productivity, personnel training, business improvement strategies are identified positively as relevant activity in their company. There is similarity in the use of technology innovation of communication strategies, focus on making more intelligent relations between users and manufacturers, it will improve the use of advanced services of the enterprise (Kamp, 2016).

Now talking about Business variable, the highest value is located for group 3, the perception about technology implementation in the enterprise,

Competitive advantage, strategies for the creation of new products, indicate positive acceptation of their implementation inside of the company. Industry 4.0 integration have complicated jumps in the SMEs, required investment of their systems are obstacle that stop their development, if this tendency continuous could affect the economy activity (Dassisti, Giovannini, Pasquele, Chimienti \& Panetto, 2018). The international commercial dynamic includes companies that make up value chain and altogether are part of the product competitiveness (Huerta, 2014).

Likewise, the "Social Responsibility" variable. The highest score is located in group three, the appreciation for harmonized process that doesn't affect the environment, sensibilization about the importance of taking care the environment and waste from product control, indicate that company's activities are being better valued.

"Product" and "Technology" showed results very similar among groups. This indicate that product life cycle, technology implementation in the business and the benefits of digitization are valuated same way for the three groups of enterprises.

Something similar happens to the variable "technology", where the acquisition of technology, technological investment budget and use of electronic media, are perceived the same way for the three groups of the company. Consistent with the findings of Sueptaetrakun (2018), innovation has a positive influence on the performance of the organization, the types of technological innovation influence the growth of SMEs through the promotion of the company's technological capacity. 
The companies that make up group three presented better performance for the adoption of I4.0 while those that make up groups one and two can see some limitations that place them below the level of group three.

\section{Conclusions}

It is indicated that the obtained results by the personnel in charge of the business automobile distribution companies, which their level of knowledge recognize and perceive favorably the issues associated with I4.0, know their product well and try to implement technological aspects such as strategies to improve and compete in this sector; this allows us to visualize that automobile dealer are very aware about their importance within chain value of the automotive sector and the high competitiveness that exists between them.

The knowledge of productive processes, the continuous improvement, implementation of new technology, personnel training, competitive advantages of the company and processes harmonized with the environment are some aspects better evaluated by the members of group three, integrated by Volkswagen Megamotors, Peugeot, Mitsubishi Tampico, Renault Tampico and Nissan Tampico. In this group, technology-based business strategies are better identified; likewise, they will have the ability to react better to competition strategies implemented in the automotive sector.

\section{Limitation and address to future investigations.}

This investigation works for enterprise that offer retail products as automobiles, it is focused on structure of the value chain, services and product quality; if this require utilize for other business sector could work if the enterprise have affinity in the productive process, on the contrary it have to adapt new necessities to evaluate.

\section{References}

Basurto, R. (2013). Structure and recomposition of the global automotive industry. Journal of economic literature, 10(30), $75-90$.

Baena, F., Guarin, A., Mora, J., Sauza, J. \& Retat, S. (2017). Learning Factory: The path to Industry 4.0. 7th Conference on Learning Factories. doi: 10.1016/j.promfg.2017.04.022

Blanco, M., González, K. \& Rodríguez, J. (2017). Proposal of UAM architecture in industry 4.0 in the supply chain from the perspective of industrial engineering. Solidaria, 13(23), 77-90.

Blanco, R., Fontrodona, J. \& Poveda, C. (2017). Industry 4.0: the state of the matter [La industria 4.0: el estado de la cuestión). Economía Industrial, 403, 151-164.

Bearzotti, L. (2017). Industry 4.0 and supply chain management: the challenge of the new industrial revolution. Gaceta Sansana, 3(8), 1-7.

Cano, J. \& Baena, J. (2015). Trends in the use of information and communication technologies for international negotiation [Tendencias en el uso de las tecnologías de información y comunicación para la negociación internacional). Estudios gerenciales, 31, 335-346.

Carbajal, J. (2017). The Fourth Industrial Revolution or Industry 4.0 and its Impact on Higher Education in Engineering in Latin America and the Caribbean. 15th LACCEI. 19-21 July 2017, Boca Raton Fl, United States.

Catalan, C., Serna, F. \& Blesa, A. (2015). Industry 4.0 in the degree of Electronic and Automatic Engineering. UPCommons, 327-332.

Chen, J. (2012). Advances in Hospitality and Leisure. Bingle: Emerald Group Publishing, Vol. 8.

Cocca, P., Marciano, F., Rossi, D. \& Alberti, M. (2018). Business Software Offer for Industry 4.0: the SAP case. IFAC.1200-1205.

Cornelis, J. \& Strandhagen, J. (2017). An Industry 4.0 research agenda for sustainable business models, Procedia CIRP, 63, 721-726.

Da, L., Xu, E. \& Li, L. (2018). Industry 4.0: state of the art and future trends, International Journal of Production Research. doi: 10.1080/00207543.2018.1444806

Dassisti, M., Giovannini, Pasquale, M., Chimienti, M. \& Panetto H. (2018). An approach to support Industry 4.0 adoption in SMEs using a core-metamodel. https://doi.org/10.1016/j.arcontrol.2018.11.001.

Esguerra, G. \& Contreras, F. (2016). Electronic leadership, an unavoidable challenge for today's organizations [Liderazgo electrónico, un reto ineludible para las organizaciones de hoy). Estudios gerenciales, 32, 262-268.

Ford. (2019). Ford 4.0: the New Industrial Revolution. Ford Website: https://www.ford.mx/blog/legado/nuevarevolucion-industrial-201809/

Germán, A., Santos L. \& Fabián, N. (2019). Industry 4.0 technologies: implementation patterns in manufacturing companies. International Journal of Production Economics. doi: 10.1016/j.ijpe.2019.01.004 
González, G. \& Rodríguez, F. (2017). Automation of an industrial power plant through distributed. RISTI, 27(6).

Joyanes, L. (2017). Cybersecurity: public-private collaboration in the era of the fourth industrial revolution Industry 4.0 [Ciberseguridad: la colaboración público-privada en la era de la cuarta revolución industrial Industria 4.0). Cuaderno de estrategía, 185, 16-64.

Hair, J., Hult, G. \& Ringle, C. (2016). Primer on Partial Least Squares Structural Equation Modeling (PLS-SEM), 2 ed. Nueva York: SAGE Publications.

Huerta, A. (2014). The Mexican manufacturing industry seen from within the context of industrialization of China and India [La industria manufacturera mexicana vista desde en el contexto de industrialización de China e India). Economía Informa, 38, 41-69.

Kamp, B. (2016). Servitization as a strategy for the competitive evolution of the industry. [on line]. Available at: https://www.orkestra.deusto.es/es/investigacion/publicaciones/articulos-cientificos/1083-servitizacionestrategia-evolucion-competitiva-industria

Lu, Y. (2017). Industry 4.0: A survey on technologies, applications and open research issues. Journal of Industrial Information Integration, 6, 1-10.

López, M., Pereira, A. \& Alves, A. (2017). Smart products development approaches for Industry 4.0. Procedia Manufacturing. 13, 1215-1222. doi: 10.1016/j.promfg.2017.09.035

López, A, (2011). The control of industrial processes and their influence on maintenance [El control de procesos industriales y su influencia en el mantenimiento). Ingeniería Industrial. [on line]. Available at: http:/ / www.redalyc.org/articulo.oa?id=337428495003

Méndez, A. (2017). Talent migration as a development strategy: Mexico-Japan [Migración de talentos como estrategia de desarrollo: México-Japón). Revista problemas de desarrollo, 190(48), 137-164.

Micheli, J. \& Oliver, R. (2017). Software companies in Mexico and their links to local development [Empresas de software en México y sus vínculos con el desarrollo local). Revista problemas de desarrollo, 190(48), 37-59.

Müller, J. \& Voigt, K. (2018). The Impact of Industry 4.0 on Supply Chains in Engineer-to-Order Industries - An Exploratory Case Study. IFAC, 122-127.

Munive, M. (2014). Detonators of technological modernization in the graphic industry of Mexico: a methodology and a case of success [Detonadores de la modernización tecnológica en la industria gráfica de México: una metodología y un caso de éxito), 16(3), 317-334.

Ortega, C. (2014). Inclusion of ICTs in the Colombian company. Suma de negocios. 5 (10), 29-33.

Ortíz, S. (2017). Mexico's commercial relationship with the United States and China in the 21st century: effects on the local integration of the Mexican productive apparatus. Economía Informa. 407. 40-52.

Pérez, L., Saucedo., Salais, T. \& Marmolejo, J. (2016). Characterization of a business model within the framework of Industry 4.0. Congreso Internacional de Logística y Cadena de Suministro. [en línea]. Available at: https://www.researchgate.net/publication/320336233_Caracterizacion_de_modelo_de_negocio_en_el_marco _de_industria_40

Robayo, P. (2016). Innovation as a process and its management in the organization: an application for the Colombian graphic sector. Suma de negocios. 7,125-140.

Rodríguez, M., Balestrini, S., Balestrini, S., Romero, M. y Rodríguez, C. (2002). Analysis of the industrial strategic sector [Análisis del sector estratégico industrial). Revista de Ciencias Sociales, 7(1), 135-156.

Rodríguez, J., Sierra, J., Villazón, M. Cabrera, A., Sosa, V. \& Cortizo, J. (2018). Design engineering in surgery. How to design, market surgical devices made with 3D printing? Cirugía Española.

https://doi.org/10.1016/j.ciresp.2017.12.007

Román, R. (2010). Success factors in the implementation of information and communication technologies in health systems [Factores de éxito en la implementación de tecnologías de información y comunicación en los sistemas de salud). Medicina Clínica, 134(1), 39-44.

Schoeder, W. (2016). The German Industry 4.0 strategy: Rhenish capitalism in the era of digitalization. [on line]. Available at: http://fes-madrid.org/media/2017_FESpublicaciones/FES_Industria_4.0.pdf

Setó, D. \& Angla, J. (2011). Nature of the Company's Social Responsibility (CSR) relationship and the financial result. Revista Europea de Dirección y Economía de la Empresa, 20(4), 161-176.

Santos, K., Loures, E., Piechnicki, F. \& Canciglieri, O. (2017). Opportunities Assessment of Product Development Process in Industry 4.0. Procedia Manufacturing, 11, 1358-1365.

Santos, L., Brittes, G., Fabián, N. \& Germán, A. (2018). The expected contribution of Industry 4.0 technologies for industrial performance. International Journal of Production Economics, 204, 383-394.

SIEMENS. (2019). The future of the industry: Industrial Digitalization. 2019. Sitio web:

https://w5.siemens.com/spain/web/es/el-futuro-de-la-industria/pages/el_futuro_de_la_industria.aspx

Sueptraetakun, W. (2018). Determinants of collaboration and innovation towards organization performance within Thailand's automotive parts industry. Journal of Business and Retail Management Research (JBRMR), Vol. 13 Issue 2. 


\section{Appendix-Questionnaire}

\begin{tabular}{|c|c|c|c|c|c|c|c|c|c|}
\hline Categories & No & $\begin{array}{l}\text { Questions about the activities that enterprise } \\
\text { realize }\end{array}$ & $\begin{array}{l}\text { strongly } \\
\text { disagree } 1\end{array}$ & 2 & 3 & 4 & 5 & 6 & $\begin{array}{l}\text { strongly } \\
\text { agree } 7\end{array}$ \\
\hline \multirow{5}{*}{ 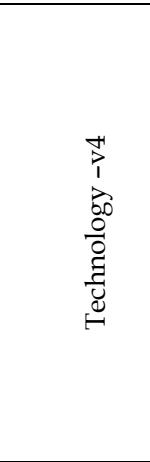 } & 16 & $\begin{array}{l}\text { Do you agree to acquire new technologies to } \\
\text { improve enterprise's production and } \\
\text { competitiveness? }\end{array}$ & & & & & & & \\
\hline & 17 & $\begin{array}{l}\text { Do you know the terms of basic, intermediate } \\
\text { and strategic technology? }\end{array}$ & & & & & & & \\
\hline & 18 & $\begin{array}{l}\text { Do you identify if the institution has an } \\
\text { assigned budget for the technology } \\
\text { implementation? }\end{array}$ & & & & & & & \\
\hline & 19 & $\begin{array}{l}\text { Do you consider that the Company has an } \\
\text { adequate Bandwidth to fulfill your necessities? }\end{array}$ & & & & & & & \\
\hline & 20 & $\begin{array}{l}\text { Do you consider that your company utilize } \\
\text { electronic means of diffusion as a competitive } \\
\text { differentiator? }\end{array}$ & & & & & & & \\
\hline \multirow{5}{*}{ 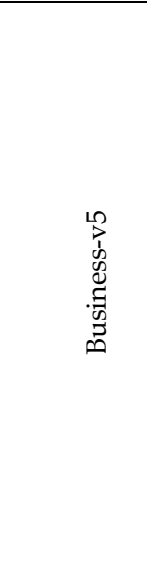 } & 21 & $\begin{array}{l}\text { Can you indicate the level of technological } \\
\text { implementation that facilitate your clients } \\
\text { purchase in your enterprise? }\end{array}$ & & & & & & & \\
\hline & 22 & $\begin{array}{l}\text { Do you agree of making a novel proposal of } \\
\text { technological base as competitive advantage in } \\
\text { your company? }\end{array}$ & & & & & & & \\
\hline & 23 & $\begin{array}{l}\text { Do you consider that industry } 4.0 \text { stands out } \\
\text { the transcendence as base of the new } \\
\text { economy? }\end{array}$ & & & & & & & \\
\hline & 24 & $\begin{array}{l}\text { Can you indicate in what level you agree that } \\
\text { technology must be strategic part of their } \\
\text { business model? }\end{array}$ & & & & & & & \\
\hline & 25 & $\begin{array}{l}\text { Do you agree that organization is obligated to } \\
\text { strategically transform for the creation of new } \\
\text { products, services and business model } \\
\text { oriented to a new type of client? }\end{array}$ & & & & & & & \\
\hline \multirow{5}{*}{ 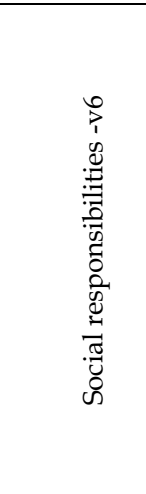 } & 26 & $\begin{array}{l}\text { Do you agree that utilized processes in your } \\
\text { enterprise are harmonized to do no harm the } \\
\text { environment? }\end{array}$ & & & & & & & \\
\hline & 27 & $\begin{array}{l}\text { At what level does your personnel realize } \\
\text { activities linked to the environment culture in } \\
\text { and out of the company? }\end{array}$ & & & & & & & \\
\hline & 28 & $\begin{array}{l}\text { Is your company allocated resources to raise } \\
\text { awareness of the importance of the } \\
\text { environment? }\end{array}$ & & & & & & & \\
\hline & 29 & $\begin{array}{l}\text { At what level does your enterprise respects } \\
\text { normativity in matter of industrial and } \\
\text { environmental security? }\end{array}$ & & & & & & & \\
\hline & 30 & $\begin{array}{l}\text { Scraps derivates from products and services } \\
\text { are controlled and are sheltered. }\end{array}$ & & & & & & & \\
\hline \multicolumn{2}{|c|}{ Control question } & $\begin{array}{l}\text { At what level do you consider that your } \\
\text { Company find in regard of industry } 4.0\end{array}$ & & & & & & & \\
\hline
\end{tabular}

